\title{
Molecular Transistor Based on the Biphenyl Substituents
}

\author{
A.G. Malashenko 1,*, P.A. Kondratenko², Y.M. Lopatkin ${ }^{1}$, A.Y. Derevyanchuk ${ }^{1}$ \\ 1 Sumy State University, 2, Rymskogo-Korsakova st., 40007 Sumy, Ukraine \\ ${ }^{2}$ National Aviation University, 1, Komarova ave., 03680 Kiev, Ukraine
}

(Received 19 September 2016; revised manuscript received 22 November 2016; published online 29 November 2016)

\begin{abstract}
It was investigated the physical processes in the molecules, which have properties required in case of using as molecular switches, transistors, or other electronic elements of future computers. Studies show that in the molecules of biphenyl substituents the angle between the planes of the phenyl rings depends on the magnitude of the applied external electric field. So, the ratio of squares of cosines of the angles between the phenyl groups in the field 0.01 a.u. and without field reaches 18 . It significantly changes the ability of electrons to move along the long axis of the molecule. By varying the nature of the substituents, we can obtain the molecule characteristics that make these molecules promising for future using. This effect provides the use of biphenyl substitutes as transistors in electrical circuits constructed on separate molecules.
\end{abstract}

Keywords: Moletronics, Biphenyl, Substituents, Switch, Transistor.

DOI: 10.21272/jnep.8(4(1)).04034
PACS numbers: 31.15. - p, 31.15.bu, 33.15.Dj,

31.10.z, 33.15.Hp

\section{INTRODUCTION}

One of the directions of use of the managed molecule properties is creating of the future computer components. Together with this the new problems arise associated with miniaturization of memory elements, switches, transistors, etc., using the individual molecules.

Work is mainly focused on the study of electron transfer through a single molecule, fixed between the two electrodes. The flow of electrons through a structure depends not only on the conditions at the contacts, but also on the structure of the molecular orbitals.

Nowadays it is carried out the intensive search of possibility to create the electronic circuit elements, which are the individual molecules (switches, transistors, etc.) [1-8].

To create molecular devices that retain their characteristics when re-use, it is possible to use the conformational conversion of the molecule. The biphenyl substituents can be carried to these molecules [9-13].

In the work [11] at the study of the physical properties of the biphenyl substituents it was used a theoretical approach, that argues use of biphenyl as a molecular electronic device.

To investigate the possible use of molecular systems as an electronic element the biphenyl molecule was also taken in [12] as a basis, but the object of study is a somewhat cumbersome system.

Experimental work [13] can be considered as the most thorough one. It has been suggested that a single molecule can function as an active electronic component, have been developed a number of methods to measure the charge transfer, have been studied conjugation of molecules with metal contacts, have been considered the different connection between the phenyl rings, as well as considered the conformational conversion and it was concluded about the role of $\pi$-conjugate system at the transfer of charge.
Despite the depth and thoroughness of execution in previous works there are not covered all sides of the charge transfer process through the biphenyl molecule.

In this paper, it was suggested that the degree of homogeneity of the electric field, its direction with respect to the molecular axis, the polarity, the possibility to control the behavior of biphenyl through the various substituents should influence on this process.

Investigation of these issues became the purpose of the present study.

The electrons and holes can be transported along the long axis of the biphenyl molecule using energy levels of $\pi$-electron system. Ideally, when the $\pi$-electronic clouds of both phenyl fragments lie in one plane, the efficiency of charge transfer along the molecule reaches its maximum. However, creating the flat structure of the molecule is impossible due to the repulsive forces action between electrical charges localized on the substituents in the ortho-positions of both phenyl fragments.

Energy of the $\pi$-electron system depending on the value of dihedral angle $\varphi$ between the phenyl fragments can be described on the qualitative level by the expression:

$$
E_{1}=A \cos ^{2} \phi, A<0
$$

On the other hand, energy of the electrostatic repulsion between the substituents localized in orthopositions of the phenyl fragments can be described by the formula:

$$
E_{2}=\left(\frac{q_{1} q_{2}}{2 r \sin (\phi / 2)}\right)+\left(\frac{q_{2} q_{3}}{2 r \sin (\phi / 2)}\right),
$$

where $q_{1}$ and $q_{2}$ are the magnitudes of electric charges on two substituents in the ortho-positions of one phenyl fragment, $q_{3}$ is the value of electric charge on the substituent in the ortho-position of the second phenyl

*'malashenko@oeph.sumdu.edu.ua 
fragment, $r$ is distance from the charge localized on the substitute in the ortho-position of the phenolic fragments to the long axis of the molecule.

When the sum of two energies of interaction reaches a minimum, the equilibrium orientation of the molecule is set.

\section{OBJECT AND METHOD OF RESEARCH}

Object of research are biphenyl molecules which can be used as components of molecular electronics, since it is possible to control the angle $\varphi$ between the phenyl fragments that provides control the value of conductivity along the long axis of the molecule.

$$
-\mathrm{NO}_{2}
$$

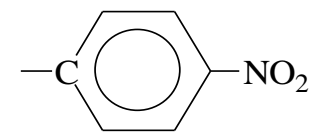

$\mathrm{R}_{1}$

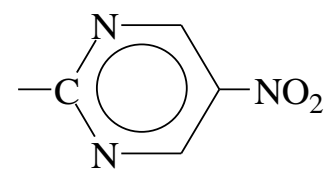

$\mathrm{R}_{3}$
$\mathrm{R}_{2}$

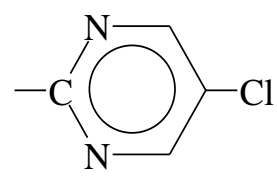

$\mathrm{R}_{4}$
Fig. 1 - Biphenyl substituents

The study of the geometric structure of the biphenyl substituents (Fig. 1) showed [9, 10,14] that the angle between the planes of two phenyl groups of the biphenyl molecules (Fig. 2) depends essentially on the nature of the substituent $\left(\mathrm{R}=\mathrm{NO}_{2}, \mathrm{CN}, \mathrm{Cl}, \mathrm{NH}_{2}\right)$ in the ortho-position of the second phenyl ring. It happens because the charge $\mathrm{q}_{3}$ depends on the nature of the substituent $R$. It is important that charges $q_{1}$ and $q_{2}$ reach the maximum possible value which is achieved using $\mathrm{CN}$ or $\mathrm{NO}_{2}$ substituent group.

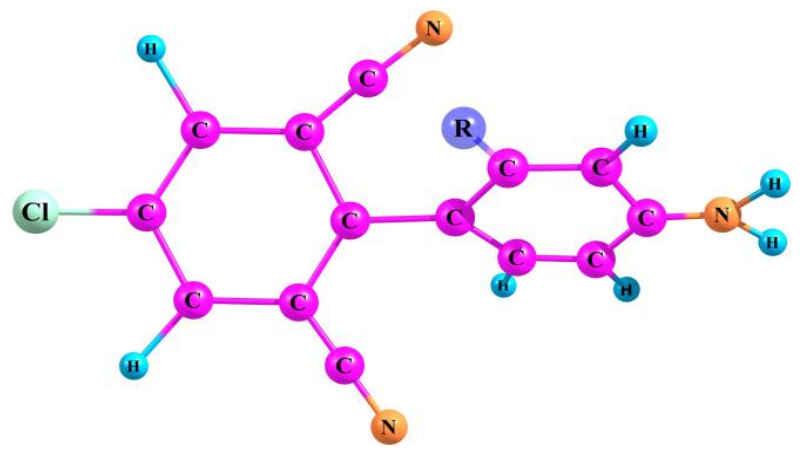

Fig. 2 - Biphenyl molecule with substituent $R$

It is important that the excess charge of the substituent depends on the nature of the substituent. Substituents which have acceptor properties provide repulsion (except steric effects) of the adjacent phenyl ring of cyano groups.

As a consequence, the phenyl fragments of these molecules are rotated at an angle close to $90^{\circ}$ relative to each other. In this case, the $\pi$-conjugation between the phenyl fragments are absent. Thus, the transfer of the charge (electric current) along the molecule be- comes impossible. Placing of the molecule into an electric field directed along the molecule's axis leads to a charge displacement (polarization) along the molecule's axis. This polarization leads to the change in the angle between the phenyl fragments. This effect enables the use of biphenyl derivatives as switches in electrical circuits, built on separate molecules (moletronics).

The study of the physical properties of biphenyl substituents led to the idea that a change in the charge state of the substituents can be carried out by a transverse electric field, i.e. these molecules can be used as field-effect transistors (FET). It is logical to use long molecular fragment, oriented parallel to the transverse direction (relative to the axis of the biphenyl molecule) of the electric field as the substituent. In all cases the electric field is chosen perpendicular to the axis of biphenyl in the plane of the phenyl ring which bears the substituent $\mathrm{R}$ only in one ortho-position of the second phenyl fragment. The direction of the field through the substituent to the axis of biphenyl was considered as positive one. Thus, the positive field pulls the electrons to the substituent, and negative one pulls them from the substituent. It can cause a rotation between the two phenyl rings, causing a change in $\pi$-electron interface and hence conductivity of the molecule along the phenyl fragments. Thus, we will have a molecular transistor with the molecular fragment as a base.

Quantum chemical investigations were made using the semi-empirical method AM1[15, 16]. At first, the geometric structure of the molecule in the configuration interaction absence was found. Next to find the energy minimum depending on the relative orientation of the phenyl groups the calculations were performed by varying the angle in the vicinity of the found values, taking into account the configuration interaction between 12 occupied molecular orbitals (MO) and 12 unoccupied MO. The results of this research were processed by the method of least squares approximating the resulting dependence by the second order curve. This allows to achieve high accuracy to find the angle between the phenyl fragments for a given value of the electric field. Molecule which we examine in the FET mode is oriented so that the long axis of the molecule is perpendicular to the field lines of an external electric field. Furthermore, the electric field lines must lie in the plane of the phenyl fragment and the substituent is at the ortho-position of this fragment and it is acting as the transistor base.

The magnitude and direction of the applied electric field are set by software.

\section{RESULTS OF RESEARCH AND DISCUSSION}

Investigation of the dependence of rotation angle between the phenyl rings in the molecule transistor mode (Fig. 3(a)) shows that using of non-uniform electric field (the distance between nitrogen atoms and boron ranged from 6 to $2.8 \AA$ ) allows rotation of the phenyl groups in biphenyl only 1-1.2 degrees.

Quite a different result is obtained by using a uniform electric field (Fig. 3(b)). In this case, the sensitivity of the molecules to the electric field in the FET mode is significantly greater since the uniform electric field interacts with all valence electrons of the molecule. 


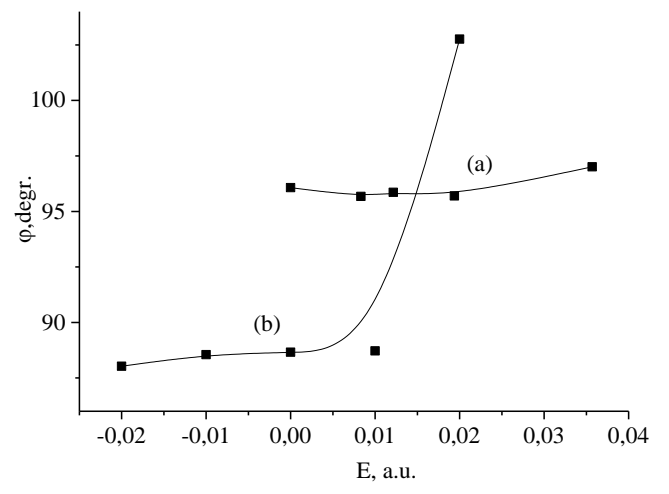

Fig. 3-The dependence of the rotation angle between the phenyl rings of the biphenyl molecule with the substituent $R_{1}$ on the intensity of non-uniform (a) and uniformelectric field (b)

In particular for $E=0.02$ a.u. the uniform electric field sensitivity of the molecule is an order of magnitude greater than the point charge sensitivity.

On the other hand, the relation between the rotation angle of the fragments in the case of placing the molecule in a uniform electric field is rather complicated, since the effect depends on the influence of all molecule valence electrons. This dependence leads to the fact that such a molecule even in the FET mode can be used only as a switch. However, there is a very important detail: there is the electric field strength at which the angle between the phenyl rings is $90^{\circ}$. And it will provide a large relative change in the amount of current which will flow along the axis of biphenyl.

We try to remove $R_{1}$ substituent from the axis of the molecule by inserting an additional phenyl group (substituent $R_{2}$ ) between them and place the molecule into the uniform electric field (Fig. 4).

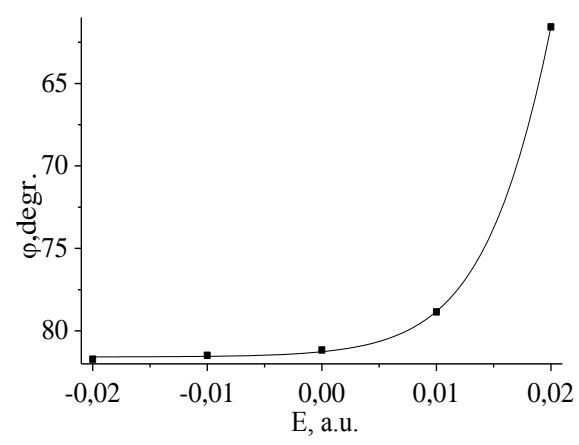

Fig. 4-The dependence of the rotation angle between the phenyl rings of the biphenyl molecule with a substituent $R_{2}$ on the intensity value of the uniform electric field

Since the control group of atoms (nitro group) is removed from the bond between the phenyl groups, the equilibrium angle between them is reduced to $81^{\circ}$. It causes the second effect: the insensitivity of the molecule to the electric field directed from the long axis of the molecule to the substituent (negative direction) and a significant sensitivity to the positive direction of the field, which shifts the electron cloud to the substituent. The effect is quite significant, since the angle of rotation between the phenyl fragments changes to $20^{\circ}$. However, the relative change in the conductivity of the molecule, which is determined by ratio of squares of cosines of $61^{\circ}$ and $81^{\circ}$, is only 9.6. Rapid increase of the dependence of the rotation angle on the electric field may allow the using of such transistor in the mode switch.

We achieve this effect because the phenyl group in the substituent $R_{2}$ does not contain active atom, which has a significant charge focused on it, the value of which could be controlled. Therefore, we have replaced the $R_{2}$ substituent with $R_{3}$.

Calculations have shown that in the absence of an external field, in the molecules at equilibrium state with a substituent $R_{3}$ the angle between the phenyl rings $\varphi_{\min }=90.855^{\circ}$.

After that we put the molecule into an external electric field caused by the presence of the anion (Table 1). Value of the field is changed by varying distances from the $\mathrm{CN}_{2}$ group of the substituent to anion along the axis.

Table 1 - The dependence of the rotation angle between the phenyl rings of the biphenyl molecule with substituents $R_{3}, R_{4}$ on the intensity values of non-uniform and uniform electric fields

\begin{tabular}{|c|c|c|c|c|}
\hline \multirow{2}{*}{ Substituent } & \multicolumn{2}{|c|}{$\begin{array}{c}\text { Uniform elec- } \\
\text { tric field }\end{array}$} & \multicolumn{2}{c|}{$\begin{array}{c}\text { Non-uniform } \\
\text { electric field }\end{array}$} \\
\cline { 2 - 5 } & $E$, a. u. & $\varphi$, degr. & $E$, a. u. & $\varphi$, degr. \\
\hline \multirow{3}{*}{$R_{3}$} & 0 & 92.5 & 0 & 90.855 \\
\cline { 2 - 5 } & -0.01 & 100.5 & 0.015 & 92.25 \\
\cline { 2 - 5 } & 0.01 & 101 & 0.023 & 94.02 \\
\hline \multirow{3}{*}{$R_{4}$} & 0.01 & 87 & -0.098 & 91.46 \\
\cline { 2 - 5 } & -0.01 & 89 & -0.02 & 91.5 \\
\cline { 2 - 5 } & -0.028 & 107 & -0.035 & 91.65 \\
\hline
\end{tabular}

Thus, the study of biphenyl molecules with substituent $R_{3}$, chosen as a model of molecular transistor, shows that the angle between the phenyl rings can be controlled by external non-uniform electric field of the small value. Although the initial angle between the phenyl fragments are somewhat above $90^{\circ}$, squares of cosine ratio of angles between the extreme points reached 25 . The molecule placed in the uniform electric field provides significantly $\left(22^{\circ}\right.$ against $\left.3.8^{\circ}\right)$ better results than in the non-uniform field.

Comparing data from Fig. 2 and obtained data for the substituent $R_{3}$ (Table 1 ) we can see improved results using the biphenyl molecule with substituent $R_{3}$ in FET mode. It is interesting that the angle is increased at switching on of the external uniform field, regardless of the polarity of the field. Variant $\varphi=90^{\circ}$ is absent. Nevertheless, the ratio of squares of cosines of the angles between the phenyl groups in the field 0.01 a.u. and without field reaches 18 . We can operate in such fields when the field does not affect the stability of the molecule.

Finally, it is important to upgrade the last variant by replacing only the final nitro-group by the chlorine atom $\left(R_{4}\right)$.

In this molecule the substantial negative charge focuses on the nitrogen atoms of the substituent and the magnitude of this charge depends on the intensity of the uniform electric field. The dependence of the rotation angle between the phenyl rings on the applied 
uniform electric field is shown in Table 1.

Attempts to solve the same problem using a point charge $\mathrm{BF}_{4}$ - does not provide good results: the displacement field gave only 0.11. This table does not illustrate the dependence $\varphi(E)$ at increasing of the electric field in the positive direction, as it turns out, this molecule is destroyed (since the chlorine anion is separated on the long molecule axis).

Comparing this result with the data for $R_{3}$-biphenyl indicates that both molecules can be used in the transistor mode. However, the substituent $R_{3}$-biphenyl is more sensitive to the uniform electric field than the substituent $R_{4}$ about 6 times (for the same values of $E=0.01$ a.u.). However, in the case of $R_{4}$-biphenyl it is possible to set the angle of $90^{\circ}$ between the phenyl fragments. So the application opportunities of this molecule in the FET mode are essentially expanded.

\section{CONCLUSIONS}

Thus, based on the research of influence of the external electric field on the geometric structure of the substituted biphenyl the following conclusions may be drawn:

1. When using of electron-acceptor substituents in the ortho-position of the phenyl fragments of biphenyl molecule the value of dihedral angle between these fragments can reach $90^{\circ}$.

2. Research of the nitro-substituted biphenyl molecules $R_{1}$ showed that at the action of the uniform electric field directed perpendicular to the axis of the molecule, the magnitude of the negative charge on the substituent is decreased which leads to the change in the dihedral angle between the phenyl fragments. The angle between the phenyl fragments is sharply increased in excess of the value of the field $E=0.01$ a.u., that allows the use of this molecule as a switch even in the transistor mode.

3. Placing of substituted biphenyl in a non-uniform electric field created by a point charge, reveals much smaller (an order of magnitude) effect than when placing in a uniform electric field.

4. Distancing of nitro groups from the axis of biphenyl using the neutral $R_{2}$ insert leads to decreasing of the angle between the phenyl fragments from $90^{\circ}$ to $82^{\circ}$. However, in the uniform external field $E=0.02$ a.u. the additional angle of about $20^{\circ}$ appears, ensuring opportunity of using of this molecule as in the mode of switcher and in the mode of the field effect transistor. The molecule is sensitive only to positive polarity of the electric field, which increases the magnitude of the negative charge on the nitro group.

5 . Replacement of the substituent $R_{2}$ by the substituent $R_{3}$, which contains the active nitrogen atoms that are able to control the angle between the phenyl fragments, assists to establish the initial angle close to $90^{\circ}$ and increase the value of this angle regardless of the polarity of a uniform electric field. Of all the tested substituents in molecule biphenyl the substituent $R_{3}$ provide the greatest sensitivity of the molecule to the electric field, allowing the use of this molecule in the mode of the field effect transistor with the field values $\sim 0.01$ a.u.

6. Substituent $R_{4}$ also contributes to the appearance of sensitivity to the electric field, but lesser than in the case of $R_{3}$. However, in this case the possibility of establishing of angle $90^{\circ}$ between the phenyl fragments is realized, that significantly increases the possibility of using the molecule $R_{4}$-biphenyl as a field-effect transistor.

7. An ability to control the molecular structure of biphenyl molecules indicates the possibility to control the spectral position and fluorescence quantum yield of molecules.

\title{
Молекулярний транзистор на основі замісників дифенілу
}

\author{
А.Г. Малашенко ${ }^{1}$, П.О. Кондратенко을. Ю.М. Лопаткін ${ }^{1}$, А.Й. Дерев'янчук ${ }^{1}$ \\ 1 Сулський державний університет, вул. Рилського-Корсакова, 2, 40007 Сули, Украӥна \\ 2 Національний авіаційний університет, пр. Кослонавта Коларова, 1, 03680 Київ, Украӥна \\ Було досліджено фізичні процеси в молекулах, які мають властивості необхідні у випадку їх вико- \\ ристання у ролі молекулярних перемикачів, транзисторів або інших елементів майбутніх \\ комп’ютерів. Дослідження показують, що в молекулах дифенілу з замісниками кут між площинами \\ фенільних кілець залежить від величини прикладеного зовнішнього електричного поля. Таким чи- \\ ном, відношення квадратів косинусів кутів між фенільними групами в полі величиною 0,01 а.о. і без \\ поля досягає 18. Це істотно змінюе здатність електронів рухатися уздовж довгої осі молекули. Зміню- \\ ючи природу замісників, ми отримаємо характеристики молекули, які роблять ці молекули перспек- \\ тивними для майбутнього використання. Такий ефект дає можливість використовувати замісники \\ дифенілу в якості транзисторів в електричних схемах, побудованих на окремих молекулах.
}

Ключові слова: Молетроніка, Дифеніл, Замісники, Перемикач, Транзистор. 


\title{
Молекулярный транзистор на основе заместителей дифенила
}

\author{
А.Г. Малашенко ${ }^{1}$, П.А. Кондратенко ${ }^{2}$ Ю.М. Лопаткин ${ }^{1}$, А.И. Деревянчук ${ }^{1}$ \\ 1 Сулский государственный университет, ул. Рилского-Корсакова, 2, 40007 Сульь, Украина \\ 2 Национальный авиационньй университет, пр. Кослонавта Коларова, 1, о3680 Киев, Украина
}

\begin{abstract}
Были исследованы физические процессы в молекулах, которые имеют необходимые свойства в случае их использования в качестве молекулярных переключателей, транзисторов и других элементов будущих компьютеров. Исследования показывают, что в молекулах дифенила с заместителями угол между плоскостями фенильных колец зависит от величины приложенного внешнего электрического поля. Таким образом, отношение квадратов косинусов углов между фенильными группами в поле величиной 0,01 а.е. и без поля достигает 18. Это существенно меняет способность әлектронов двигаться вдоль длинной оси молекулы. Изменяя природу заместителей, мы получим характеристики молекулы, которые делают эти молекулы перспективными для будущего использования. Такой эффект даёт возможность использовать заместители дифенила в качестве транзисторов в әлектрических схемах, построенных на отдельных молекулах.
\end{abstract}

Ключевые слова: Молетроника, Дифенил, Заместители, Переключатель, Транзистор.

\section{REFERENCES}

1. Asha Lather, V.K. Lamba, Himani Malik, Int. J. Eng. Sci.Chnol. 2 No 3, 460 (2012).

2. Kai Sotthewes, Victor Geskin, René Heimbuch, Avijit Kumar, Harold J.W. Zandvliet, APL Mater. 2, 010701 (2014).

3. Nicolas Roch, Serge Florens, Theo A. Costi, Wolfgang Wernsdorfer, Franck Balestro, Phys. Rev. Lett. 103, 197202 (2009).

4. A.G. Malashenko, T.N. Sakun, P.A. Kondratenko, Yu.M. Lopatkin, J. Nano-Electron. Phys. 5 No 4, 04069 (2013).

5. A.G. Malashenko, T.N. Sakun, P.A. Kondratenko, Yu.M. Lopatkin, J. Phys. Chem. 9 No 5, 160 (2014).

6. Jamshid Najafpoura, Majid Monajjemia, Hossein Aghaiea, Karim Zarea, Fullerenes, Nanotubes and Carbon Nanostructures 23 No 3, 218 (2015).

7. A.R. Champagne, A.N. Pasupathy, D.C. Ralph, Nano Lett. 5, 305 (2005)
8. Matthias Hinreiner, Dmitry A. Ryndyk, Denis Usvyat, Thomas Merz, Martin Schütz, Klaus Richter, phys. status solidi b 250, No 11, 2408 (2013).

9. A.V. Dmitriev, P.A. Kondratenko, Yu.M. Lopatkin, A.V. Glushkov, SEMST 2(8) No 3, 54 (2011).

10. O.A. Shovkoplyas, Yu.M. Lopatkin, P.A. Kondratenko, J. Nano-Electron. Phys. 5 No 1, 01012 (2013).

11. F.G. Medina, J.H. Ojeda, C.A. Duque, D. Laroze, Superlattice. Microst. 87, 89 (2015).

12. Saikat Mukhopadhyay, Ravindra Pandey, J. Phys. Chem. C 116, 4840 (2012).

13. L. Venkataraman, J.E. Klare, C. Nuckolls, M.S. Hybertsen, M.L. Steigerwald, Nature 442 No 7105, 904 (2006).

14. Paul M. Solomon, Norton D. Lang, ACS Nano 2(3), 435 (2008).

15. M.J.S. Dewar, E.G. Zoebisch, E.F. Healy, J.J.P. Stewart, J. Am. Chem. Soc. 107 No 13, 3902 (1985).

16. J.J.P. Stewart, J. Mol. Model. 10 No 2, 155 (2004). 